\title{
Implementasi Kebijakan Pemerintah Daerah Dalam Penerapan Masyarakat Ekonomi Asean Terhadap Sektor Usaha Kecil Dan Menengah Di Kabupaten Bogor
}

\author{
Asep Kamaluddin Nashir ${ }^{1}$, Nurmasari Situmeang ${ }^{2}$, Wiwiek Rukmi Dwi Astuti ${ }^{3}$ \\ ${ }^{123}$ Program Studi Ilmu Hubungan Internasional, UPN Veteran Jakarta \\ Email: wiwiek.rukmi@upnvj.ac.id
}

\begin{abstract}
Integrating the ASEAN single market through the ASEAN Economic Community requires the government to harmonize industrial policies that are able to support sustainable economic growth. The progressive development of SMEs is one of the government's efforts to increase the competitiveness of commodities in the global market. The efforts of Bogor Regency government have not shown maximum results. Export value's growth of the footwear industry is still dominated by large enterprises despite various training and education for SMEs. Therefore, public policy is needed to accommodate inter-company cooperation to increase export and production activities. In addition, local governments as policy makers and implementers must also design their policies within the framework of supporting the interests of small and medium industries.
\end{abstract}

Keywords: Small and Medium Enterprises, Footwear, Kabupaten Bogor, ASEAN Economic Community

\begin{abstract}
Abstrak
Pengintegrasian pasar tunggal ASEAN melalui Masyarakat Ekonomi ASEAN menuntut pemerintah untuk menyelaraskan kebijakan industri yang mampu mendukung pertumbuhan ekonomi berkelanjutan. Pengembangan UKM secara progresif menjadi salah satu upaya pemerintah untuk meningkatkan daya saing komoditas di pasar global. Upaya pemerintah daerah Kabupaten Bogor belum menunjukkan hasil yang maksimal. Pertumbuhan nilai ekspor industri alas kaki masih didominasi oleh industri dan usaha besar meskipun berbagai pembinaan untuk UKM/IKM telah dilakukan. Karena itu, diperlukan kebijakan public pemerintah pusat yang mampu mengakomodir Kerjasama antar perusahaan untuk meningkatkan kegiatan ekspor dan produksi. Selain itu, pemerintah daerah sebagai pengambil dan pelaksana kebijakan juga harus mendesain kebijakan mereka dalam kerangka mendukung kepentingan industri kecil dan menengah.
\end{abstract}

Kata kunci: Usaha Kecil Menengah, Alas Kaki, Kabupaten Bogor, Masyarakat Ekonomi ASEAN 


\section{Pendahuluan}

Institusi regional di Asia Tenggara yaitu Association of Southeast Asian Nations (ASEAN) telah mengalami perkembangan sejak awal berdirinya di tahun 1967. Pada KTT ke-9 ASEAN di Bali tahun 2003, dengan mengesahkan Bali Concord II, ASEAN telah menyepakati untuk membentuk suatu kawasan yang terintegrasi dalam satu komunitas negara-negara Asia Tenggara yang terbuka, damai, stabil, dan sejahtera, saling peduli, dan terikat bersama dalam kemitraan dinamis (Kementerian Luar Negeri Republik Indonesia, 2012). Komunitas ASEAN tersebut terdiri atas tiga pilar, yaitu Pilar Komunitas PolitikKeamanan ASEAN, Pilar Komunitas Ekonomi ASEAN, dan Pilar Komunitas Sosial Budaya ASEAN.

Pilar Komunitas Ekonomi ASEAN merupakan pilar yang sangat penting dalam proses integrasi kawasan Asia Tenggara tersebut. Pilar Komunitas Ekonomi ASEAN akan mewujudkan terbentuknya Masyarakat Ekonomi ASEAN (MEA), yaitu masyarakat dengan pertumbuhan ekonomi yang mampu mencapai kemakmuran yang merata dan mengentas kemiskinan. Integrasi ekonomi kawasan meliputi menurunnya biaya transaksi dalam sektor ekspor, membantu para pengusaha ASEAN dalam menemukan pasar baru bagi produk mereka, dan juga memfasilitasi aliran investasi asing ke negara-negara anggota ASEAN. Hal-hal tersebut akan mampu meningkatkan produktivitas dan pertumbuhan ekonomi kawasan.

MEA terdiri dari empat karakteristik utama, yaitu pasar tunggal dan basis produksi; kawasan ekonomi yang berdaya saing tinggi; kawasan dengan pembangunan ekonomi yang merata; dan kawasan yang terintegrasi penuh dengan ekonomi global. Tepatnya MEA resmi dimulai pada tanggal 31 Desember 2015. Dengan integrasi pasar tunggal yang mencapai 650 juta konsumen, kekuatan ekonomi MEA akan diperhitungkan dunia sebagai basis kekuatan produksi, basis kekuatan pasar, basis kekuatan modal dan basis kekuatan investasi. Maka, para kepala negara anggota ASEAN memunculkan inisiatif lanjutan untuk MEA 2015 tersebut, yaitu ASEAN Community 2025 yang merupakan visi ASEAN 10 tahun ke depan (INTRA, 2015) Pada tahun 2017, pada Pertemuan ASEAN Economic Community Council (AECC) ke-15, Menteri Perdagangan Indonesia menyatakan bahwa Indonesia telah menunjukkan komitmennya terhadap MEA secara positif melaui pencapaian implementasi tertinggi atas Prioritas Tahunan MEA pada tahun 2017, yaitu 
lainnya baru memenuhi sekitar 52\% (INTRA, 2015).

Pembangunan usaha kecil dan menengah (UKM) -salah satu program untuk menciptakan kawasan dengan pembangunan ekonomi yang meratamerupakan langkah strategis bagi Indonesia dalam menghadapi MEA. UKM merupakan motor penggerak bagi ekonomi nasional Indonesia sehingga Indonesia perlu untuk meningkatkan kualitas sektor riil tersebut. Pada krisis moneter tahun 1997-1998, UKM terbukti bertahan dari gejolak krisis karena memiliki karakteristik padat tenaga kerja, menggunakan teknologi tepat guna, dan hemat devisa.

Meskipun demikian, sektor UKM di Indonesia masih dilihat sebagai sektor yang lemah. Selain karena keterbatasan modal dan kurangnya tenaga ahli, UKM juga kurang mendapat perhatian dari pemerintah. Maka dari itu, pembangunan UKM akan menguntungkan bagi perekonomian nasional Indonesia dan meningkatkan daya saing pelaku ekonomi Indonesia dalam menghadapi MEA. UKM harus mampu bersaing dalam pasar tunggal ASEAN, yang mana sebagai pemilik pasar terbesar, Indonesia akan diperebutkan seluruh pelaku usaha di kawasan ASEAN. mengemukakan bahwa pemerintah daerah Kabupaten Bogor telah secara serius mempersiapkan daya saing UKM melalui beragam pelatihan, termasuk pembuatan SNI, HAKI, merk dan kemasan. Namun, masih terdapat sejumlah hambatan seperti produsen berskala unit kecil dan menengah keberatan lantaran proses yang sulit dan membutuhkan biaya besar; regulasi dari pemerintah yang cukup berbelit terkait persyaratan perizinan; rendahnya kualitas kelembagaan koperasi serta belum berkembangnya industri kecil dan menengah, sehingga baru mampu memproduksi saja, tetapi memiliki kendala dalam pemasaran (Situmeang, Dharmastuti, \& Nashir, 2016).

Kendati demikian, Kabupaten Bogor merupakan salah satu kabupaten terluas di wilayah Provinsi Jawa Barat, yang mempunyai potensi besar dalam membangun industri dan perdagangan. Pembangunan industri di Kabupaten Bogor terbukti mampu mendorong peningkatan laju pertumbuhan ekonomi serta menjadi penggerak perkembangan pembangunan daerah. Disamping itu juga menumbuhkan dan memberdayakan ekonomi masyarakat melalui sektor UKM dan Koperasi. Pada tahun 2016, ekspor komoditas dari Kabupaten Bogor masih didominasi oleh ekspor bidang industri 
sedangkan non industri belum begitu menonjol. Potensi hasil industri dan kerajinan Kabupaten Bogor pun cukup besar, seperti industri tekstil dan alas kaki yang menjadi komoditas unggulan Kabupaten Bogor. Namun pada umumnya para pengusaha UKM tersebut terbentur pada kendala promosi untuk menunjang pemasaran produknya.

Dalam tulisan ini, Kabupaten Bogor menjadi fokus untuk melihat implementasi kebijakan pemerintah daerah dalam penerapan masyarakat ekonomi ASEAN terhadap sektor usaha kecil dan menengah komoditas alas kaki. Pemilihan komoditas alas kaki sebagai fokus dari rencana penelitian ini adalah karena alas kaki termasuk dalam 10 besar komoditas ekspor non migas tahunan Jawa Barat, dimana selama periode 2013-2017 terus menunjukkan peningkatan (Lihat Gambar 1). Selain itu, industri alas kaki, merupakan sektor strategis dan menjadi prioritas Indonesia, melalui Kementerian Perindustrian dan Kementerian Perdagangan, untuk terus dikembangkan karena mampu memberikan kontribusi cukup signifikan terhadap perekonomian nasional. Bahkan, Indonesia adalah eksportir alas kaki terbesar keempat di Asia setelah RRT, Hong Kong, dan Vietnam. Dikutip dari laman resmi Kementerian Perindustrian, sebaran industri kecil dan mikro alas kaki di seluruh Indonesia, sebanyak 82 persen berada di provinsi Jawa Barat dan Jawa Timur. Konsentrasi sektor tersebut di wilayah Jawa Barat, meliputi Bogor, Bandung, dan Tasikmalaya. Sedangkan, Jawa Timur, berada di Pasuruan, Sidoarjo, Mojokerto, Jombang, dan Magetan (Kementerian Perindustrian Republik Indonesia, 2019). Di Kabupaten Bogor, sentra produksi alas kaki tersebar di 14 desa, dimana setiap desa mengkhususkan diri pada jenis produk, seperti sandal, sepatu anak-anak, atau sepatu olahraga (Trade Facilitation Office Canada dan The Conference Board of Canada, 2017).

\section{Gambar 1. Nilai Ekspor Non Migas Tahunan Jawa Barat Menurut Golongan Barang (Juta USD), 2013- 2017}

\begin{tabular}{|c|c|c|c|c|c|}
\hline Golongan Barang & 2013 & 2014 & 2015 & 2016 & $2017^{*} \mid$ \\
\hline [1] & [2] & [3] & [4] & [5] & [6] \\
\hline 1. Mesin / Peralatan Listik (85) & $5,422,94$ & $5,056.86$ & $4,337,04$ & $4,023.58$ & $4,073.46$ \\
\hline 2. Mesin-mesin / Pesawat Mekanik (84) & $2,742.58$ & $2,607,04$ & $2,459.23$ & $2,546,04$ & $3,127.53$ \\
\hline 3. Barang-barang Rajutan (61) & $1,977.74$ & $2,000,73$ & $1,908.75$ & $1,891,94$ & $2,184,21$ \\
\hline 4. Alas Kaki (64) & 849.11 & $1,081,13$ & $1,331.34$ & $1,447,29$ & $1,454,32$ \\
\hline 5. Kendaraan dan Bagiannya (87) & $1,293.58$ & $1,601,29$ & $1,666.60$ & $2,258,48$ & $4,496.23$ \\
\hline 6. Pakaian Jadi Bukan Rajutan (62) & $1,564.07$ & $1,586.09$ & $1,506.96$ & $1,507,80$ & $1,530.81$ \\
\hline 7. Karet dan Barang dari Karet (40) & $1,455,31$ & $1,372,44$ & $1,338.89$ & $1,378,90$ & $1,344,61$ \\
\hline 8. Serat Stafele Buatan (55) & $1,349.67$ & $1,347,07$ & $1,224.82$ & $1,111.83$ & $1,141,10$ \\
\hline 9. Kertas / Karton (48) & 978.95 & 981.87 & 920.83 & 844,99 & 921.39 \\
\hline 10. Filamen Buatan (54) & 934.74 & 934.28 & 833.10 & 798.48 & 716.98 \\
\hline Total 10 Golongan & $18,568.68$ & $18,568.81$ & $17,527.56$ & $17,809.32$ & $20,990,66$ \\
\hline Lainnya & $7,389.13$ & $7,708.02$ & $7,442,73$ & $7,470,71$ & $7,952.86$ \\
\hline Total ekpor Nonmigas & $25,957.81$ & $26,276.83$ & $24,970,30$ & $25,280.03$ & $28,943.52$ \\
\hline ;) Angka tetap sd Bulan Desember 2017 & & & & & \\
\hline
\end{tabular}

Sumber: BPS Provinsi Jawa Barat, 2018 
Dari uraian di atas dapat diasumsikan bahwa pemerintahan Kabupaten Bogor telah memiliki kesiapan dengan melakukan pengelolaan UKM yang berorientasi ekspor. Pemerintahan Kabupaten Bogor menyadari dengan jelas potensi daerahnya untuk dapat bersaing di pasar internasional, khususnya di ASEAN melalui MEA. Oleh karena itu, tulisan ini menganalisis upaya pemerintah Kabupaten Bogor melalui implementasi kebijakan pemerintah daerah dalam penerapan MEA terhadap sektor usaha kecil dan menengah alas kaki di Kabupaten Bogor.

\section{Kebijakan Publik dan Pembangunan UKM}

Dalam hubungan internasional, negara cenderung melakukan kerjasama di bidang ekonomi melalui perdagangan internasional dan investasi untuk meraih keuntungan dan mencapai kesejahteraan nasional. Perdagangan internasional dan investasi merupakan dua hal yang sangat vital bagi pembangunan ekonomi suatu negara. Pelaksanaan kedua aktivitas ekonomi tersebut berkembang melalui pandangan ekonomi liberal, yaitu pengadaan perdagangan bebas. Dalam perspektif neoliberal institusionalisme, diasumsikan bahwa negara adalah penganut nilai-nilai liberal, berorientasi pasar, dan mendukung konsep kerjasama dan absolute gains (Gilpin, 2001).

Diskursus neoliberal institusionalisme telah diperluas untuk membingkai peran negara dan non-negara, mulai dari multinational corporation (MNC) hingga UKM, dalam aktivitas perekonomian nasional dan global. Pendekatan neoliberal institusionalisme dalam pembangunan UKM merupakan bentuk penghormatan atas kegiatan dan kebebasan dari pengusaha perorangan. Pengusaha dipandang sebagai generator utama dari kekayaan dalam masyarakat, dengan menghasilkan kemajuan dan pembangunan ekonomi (Bateman, 2000). Kebebasan berusaha yang dimiliki oleh individu tersebut yang kemudian harus dilindungi oleh negara dengan memastikan tercipta dan terjaganya lingkungan yang kompetitif dan netral; melindungi hak milik, dan memiliki supremasi hukum.

Neoliberal institusionalisme melihat bahwa model pengembangan UKM dapat disuling, berdasarkan pembangunan kapasitas daerah dan pusat yang saling terhubung, lembaga pembiayaan, lembaga promosi, dan fungsi regulasi (Bateman, 2000). Model yang mengutamakan pembangunan kapasitas lokal tersebut dipersepsikan dapat mengalahkan model fundamentalis pasar. 
Kebijakan yang menunjang pembangunan UKM senantiasa ditemui baik di negara maju maupun negara berkembang. Mulai dari Uni Eropa hingga ASEAN, secara berkala menerbitkan SME Policy Index untuk melihat ketahanan sektor UKM di regionnya. Di negara maju, pembangunan UKM di bidang teknologi informasi dan komunikasi, juga pengembangan pasar dan daya saing, telah menjadi kontributor utama atas perkembangan UKM. Sementara itu, di negara berkembang, kebijakan yang dirancang untuk membantu pertumbuhan UKM berkaitan erat degan kebijakan industri dan berbagai program bantuan multilateral, seperti PBB sejak tahun 1950an (Levitsky, 1996 dalam Hervie \& Lee, 2005). Menyadari bahwa sektor UKM merupakan penunjang stabilitas nasional dan pertumbuhan ekonomi suatu negara, maka kebijakan berorientasi pembangunan UKM dibuat untuk menghadapi sistem ekonomi terbuka (Harvie \& Lee, 2005).

$$
\text { Kebijakan pemerintah dalam }
$$
mendorong pembangunan UKM dapat dikategorikan secara umum berdasarkan tujuan ekonomi suatu negara. Harvie \& Lee (2005) mengkategorikan kebijakan pemerintah yang mendukung pembangunan UKM sebagai berikut:
Tabel 1. Kategori kebijakan pemerintah

\section{yang mendukung pembangunan UKM}

\begin{tabular}{|c|c|}
\hline $\begin{array}{l}\text { Tujuan } \\
\text { Makro }\end{array}$ & $\begin{array}{ll}\text { - } & \text { penciptaan lapangan kerja } \\
\text { - } & \text { pertumbuhan ekonomi } \\
\text { - } & \text { pertumbuhan ekspor }\end{array}$ \\
\hline $\begin{array}{l}\text { Tujuan } \\
\text { sosial }\end{array}$ & $\begin{array}{ll}\text { - } & \text { redistribusi pendapatan } \\
\text { - } & \text { pengentasan kemiskinan di } \\
& \text { negara berkembang }\end{array}$ \\
\hline $\begin{array}{l}\text { Koreksi } \\
\text { kegagalan } \\
\text { pasar / } \\
\text { ketidak- } \\
\text { efisienan }\end{array}$ & $\begin{array}{ll}\text { - } & \text { adanya eksternalitas } \\
\text { - } & \text { hambatan akses pasar } \\
\text { - } & \text { jumformasi yang asimetris } \\
\text { - } & \text { ketidaksempurnaan informasi } \\
& \text { (kurangnya akses ke informasi } \\
\text { - } & \text { mentang pasar potensial } \\
& \text { bagi yang biasanya dirugikan }\end{array}$ \\
\hline $\begin{array}{l}\text { Tujuan } \\
\text { efisiensi } \\
\text { dinamis }\end{array}$ & - $\quad$ promosi inovasi \\
\hline $\begin{array}{l}\text { Sumber: } \\
\text { http://ro.u }\end{array}$ & $\begin{array}{l}\text { Harvie } \& \text { Lee. } \\
\text { du.au/commpapers/1052/. }\end{array}$ \\
\hline
\end{tabular}

Tujuan kebijakan pemerintah yang mendukung UKM melingkupi tujuan ekonomi makro, yaitu untuk menciptakan lapangan kerja karena usaha UKM yang mampu menciptakan permintaan terhadap barang akan selaras dengan peningkatan kebutuhan tenaga kerja pada UKM tersebut. Sehingga, kebijakan pemerintah biasanya adalah memberikan insentif bagi UKM untuk mengembangkan usaha mereka agar semakin berkembang. Lalu tujuan berikutnya adalah demi pertumbuhan ekonomi dan eskpor.

Selanjutnya, kebijakan pemerintah juga mengandung tujuan sosial. Pertama, redistribusi pendapatan karena para pelaku UKM dipandang sebagai golongan masyarakat menengah ke bawah sehingga 
perlu untuk dibantu. Kedua adalah sebagai upaya pengentasan kemiskinan di negara berkembang. Lebih jauh, kebijakan pemerintah dapat dilihat berdasarkan kegagalan atau ketidaksfisienan pasar yang dialami oleh negara. Kategori ini dilihat sebagai bentuk intervensi pemerintah dalam menjaga keseimbangan roda perekonomian nasional. Kompetisi pasar sering kali tidak efektif, yang justru menimbulkan persaingan yang tidak sehat seperti adanya monopoli akan sangat menganggu keseimbangan pasar. Sehingga, dalam upaya pembangunan UKM, pemerintah mengeluarkan kebijakan untuk kehadiran eksternalitas, hambatan akses pasar, ketimpangan informasi, jumlah kompetitor, kurangnya informasi tentang pasar potensial, dan juga memberikan peluang ekstra bagi UKM yang belum memiliki daya saing.

Kategori terakhir adalah tujuan efisiensi dinamis berkaitan dengan inovasi teknologi demi kesejahteraan, dan mengacu pada penggunaan sumber daya agar mampu membuat perubahan yang tepat dan sesuai untuk teknologi dan produk. Tujuan tersebut diperuntukkan agar produk yang dihasilkan oleh UKM sesuasi dengan selera/keinginan pasar saat itu, sehingga dapat dikatakan sebagai aktivitas produktif.
Praktiknya, setiap negara memiliki kebijakan publik masing-masing untuk mendukung pertumbuhan UKM-nya yang disesuaikan dengan iklim bisnis masingmasing dan dengan dampak yang juga bervariasi. Misalnya, Jepang yang mulai memberlakukan kebijakan publik guna membangun UKM publik masa gelembung ekonomi (bubble economy) Jepang yang runtuh dan berdampak pada penurunan PDB, sehingga situasi bisnis tidak mendukung terbentuknya bisnisbisnis baru (Eshima, 2003). Program yang dikeluarkan oleh pemerintah Jepang berlaku selama 10 tahun yang terbagi pada dua fase - tahap untuk mendapatkan sertifikasi dan tahap dimana penerima sertifikasi berhak untuk menerima berbagai dukungan dari pemerintah yang berupa subsidi untuk modernisasi fasilitas, penelitian dan pengembangan, pengurangan pajak untuk investasi fasilitas, pinjaman publik dengan tingkat bunga yang lebih rendah, asuransi utang, dan investasi modal ventura. Kebijakan ini pada dasarnya serupa dengan kebijakan Small Business Innovation Research (SBIR) yang diberlakukan oleh Amerika Serikat pada tahun 1982.

Keberhasilan dari implementasi kebijakan SBIR Amerika Serikat ternyata turut dialami oleh Jepang. Yoshihiro Eshima (2003) menilai bahwa kebijakan 
tersebut tergolong berhasil dalam merevitalisasi ekonomi Jepang pada masa resesi ekonomi sebab program tersebut berhasil meningkatkan penjualan hingga $231 \%$ dan lapangan pekerjaan hingga $56 \%$ bagi perusahaan penerima dibandingkan perusahaan serupa lainnya yang tidak menerima program.

Berbeda dengan negara maju, kebijakan publik untuk mendukung UKM menjadi komponen utama yang sangat penting bagi negara berkembang seperti Nigeria yang dimana hampir seluruh badan usaha merupakan UMKM. Badan usaha kecil dinilai menguntungkan bagi Nigeria dan akan menjadi semakin penting seiring berjalannya waktu. Oleh karena itu, terbatasnya kebijakan pemerintah terhadap UKM menjadi salah satu faktor terhambatnya peluang UKM untuk meningkatkan kinerjanya. Eniola dan Entebang (2015) menyebutkan bahwa Nigeria memiliki cukup banyak UKM yang berpotensi dalam meningkatkan tersedianya lapangan pekerjaan. Hanya saja, terbatasnya kebijakan pemerintah dalam mendukung kinerja UKM menjadi penghambat tercapainya potensi yang dimiliki UKM di Nigeria. Kebijakan terkait UKM yang dapat ditemukan di Nigeria adalah Small and medium Enterprises development Agency (SMEDAN) yang berupaya untuk memfasilitasi pertumbuhan sektor UKM di Nigeria, namun tanpa ada kebijakan pendukung eksplisit lainnya.

Selain terbatasnya kebijakan yang mendukung pertumbuhan UKM di Nigeria, buruknya implementasi kebijakan yang ada juga menjadi faktor sulitnya UKM di Nigeria untuk mampu bertahan (Eniola \& Entebang, 2015). Pemerintah Nigeria masih ditemukan mengalami kesulitan dalam menjalankan kebijakan fiskal yang tepat sehingga kebijakan kerap mengalami perubahan dan menyebabkan sulitnya UKM untuk bertumbuh. Meski masyarakat dan lingkungan fisik Nigeria sudah dianggap mampu menunjang sektor UKM namun hal ini masih belum diimbangi dengan infrastruktur dan kebijakan pemerintah yang memadai. Sehingga dalam penelitiannya, Eniola dan Entebang (2015) menyimpulkan bahwa kebijakan pemerintah akan sangat menentukan kinerja sektor UKM. Sehingga salah satu hal mendasar yang perlu dilakukan oleh pemerintah Nigeria adalah melakukan kajian metodis dan empiris terkait bagaimana kebijakan pemerintah mampu mempengaruhi berfungsinya sektor UKM sebab kajian tersebut belum banyak dilakukan oleh pemerintah Nigeria.

Pada studi terkait sektor UKM di negara lainnya, seperti Malaysia, UKM 
juga dinilai penting dalam meningkatkan lapangan pekerjaan meski kontribusinya terhadap PDB masih lebih rendah dibandingkan negara lain seperti Jerman, Jepang, Korea Selatan, Singapura, Tiongkok dan Thailand (Chin \& Lim, 2018). Meski demikian, karena tingginya tingkat pertumbuhan sektor UKM maka Malaysia menjadikan kebijakan untuk mendukung UKM sebagai prioritas melalui kebijakan seperti Second Industrial Master Plan 1996-2005 (IMP2), the Third 5 Industrial Master Plan 20062020 (IMP3) dan SME Masterplan (20122020). Kebijakan-kebijakan tersebut umumnya mencangkup poin seperti memberikan akses pasar, peningkatan kapabilitas teknologi, hingga akses pendanaan. Bahkan upaya yang dilakukan pemerintah bukan hanya agar UKM dapat bertumbuh secara domestik namun juga mendukung terciptanya internasionalisasi dengan membangun hubungan kerjasama bersama MNCs dan BUMN. Salah satu faktor yang turut mempengaruhi kebijakan pemerintah dalam mendukung UKM adalah definisi dari UKM itu sendiri yang kerap mengalami perubahan.

Chin dan Lim (2018) melihat bahwa yang menyebabkan rendahnya kontribusi UKM terhadap tingkat ekspor adalah adanya kepentingan politik UKM mikro dan kecil masyarakat pribumi (disebut juga
Bumiputera) di sektor jasa, seperti sektor konstruksi, yang mempengaruhi kinerja badan usaha menengah sektor manufaktur dan ekspor. Sehingga pemerintah Malaysia perlu turut memperhatikan badan usaha menengah khususnya sektor manufaktur yang memiliki kinerja dan potensi yang sangat baik. Meski demikian, program pemerintah Malaysia telah berhasil mendorong terciptanya badan usaha mikro yang mampu meningkatkan pendapatan masyarakat kelompok B40 (bottom 40\% atau kelompok dengan pendapatan ratarata RM 3000) hingga 76\%.

\section{Kerjasama ASEAN dalam Penguatan Pembangunan UMKM}

Pembangunan UKM merupakan langkah strategis menuju integrasi perdagangan Masyarakat ASEAN, dengan memfasilitasi pelaku-pelaku bisnis untuk mampu berkompetisi dalam pasar tunggal ASEAN. Perspektif neoliberal institusionalisme memandang para pelaku bisnis dipandang sebagai generator utama dari kekayaan dalam masyarakat, dengan menghasilkan kemajuan dan pembangunan ekonomi. Pada dasarnya, sektor UKM telah diakui sebagai penunjang stabilitas nasional dan pertumbuhan ekonomi suatu negara.

Pada tahun 2004, pertemuan Senior Economic Official Meeting (SEOM) dan 
ASEAN Economic Ministrial Meeting pada tahun 2004, telah disepakati pembentukan ASEAN Policy Blueprint for SME's Development （APBSD) 2004-2014. Pembentukan APBSD tersebut menunjukkan urgensi atas pembangunan UKM di ASEAN, bahkan sebelum ASEAN Charter dibentuk. Berikut adalah tujuan dari APBSD: 1) mempercepat laju pembangunan UKM, mengoptimalkan pada keragaman negara-negara anggota; 2) meningkatkan daya saing dan dinamisme UKM ASEAN dengan memfasilitasi akses mereka terhadap informasi, pasar, pengembangan sumber daya manusia dan keterampilan, keuangan serta teknologi; 3) memperkuat ketahanan UKM ASEAN untuk mampu bertahan dari kerugian ekonomi makro dan kesulitan finansial, serta menghadapi tantangan yang dalam lingkungan perdagangan yang semakin terliberalisasi; dan 4) meningkatkan kontribusi UKM ASEAN terhadap pertumbuhan ekonomi secara keseluruhan dan pengembangan ASEAN sebagai suatu kawasan (ASEAN, 2007).

Mandat APBSD sendiri dikelola oleh ASEAN SME Agencies Working Group (SMEWG) melalui Strategic Plan for ASEAN SME Development 2010-2025. Perkembangan selanjutnya, nama SMEWG diubah pada tahun 2016 menjadi ASEAN Coordinating Committee on
Micro, Small, and Medium Enterprises (ACCMSME), dan menjalankan ASEAN Strategic Action Plan for Small Medium Enterprises Development (SAPSMED) 2016-2025. Rencana aksi strategis tersebut bertujuan untuk: 1) untuk mempromosikan teknologi, produktif dan inovasi; 2) meningkatkan akses ke keuangan; 3) meningkatkan akses pasar dan internasionalisasi; 4) meningkatkan lingkungan kebijakan dan peraturan; 5) dan mempromosikan kewirausahaan dan pengembangan sumber daya manusia (ASEAN, t.t.).

Pada Pertemuan SMEWG ke-35 di Kamboja pada November 2014, disepakati 'Country Champions' untuk setiap tujuan stategis. Country Champion akan berperan sebagai aktor utama dalam memprakarsai dan/atau mengoordinasikan implementasi rencana aksi berdasarkan jadwal yang disepakati, serta juga berkonsultasi dan tunduk pada persetujuan SMEWG. Selain itu, terdapat juga Gugus Tugas untuk memastikan hasil yang tepat waktu dan ditargetkan, dan Sekretariat ASEAN juga bertindak sebagai penghubung dengan mitra dialog dan donor dalam memobilisasi sumber daya, bantuan teknis dan dana yang diperlukan untuk mendukung Country Champion dan Pemrakarsa Proyek dalam 
mengimplementasikan tindakan masingmasing (ASEAN Secretariat, 2019).

\section{Tabel 2. Daftar 'Country Champion'}

\begin{tabular}{|l|c|}
\hline \multicolumn{1}{|c|}{ Tujuan Strategis } & $\begin{array}{c}\text { Country } \\
\text { Champion }\end{array}$ \\
\hline $\begin{array}{l}\text { Meningkatkan produktivitas, } \\
\text { teknologi dan inovasi }\end{array}$ & $\begin{array}{c}\text { Thailand, } \\
\text { Vietnam }\end{array}$ \\
\hline Meningkatkan akses pembiayaan & $\begin{array}{c}\text { Malaysia, } \\
\text { Laos }\end{array}$ \\
\hline $\begin{array}{l}\text { Meningkatkan akses pasar dan } \\
\text { internasionalisasi }\end{array}$ & $\begin{array}{c}\text { Singapura, } \\
\text { Thailand }\end{array}$ \\
\hline $\begin{array}{l}\text { Meningkatkan iklim peraturan } \\
\text { dan kebijakan yang kondusif }\end{array}$ & $\begin{array}{c}\text { Kamboja, } \\
\text { Indonesia }\end{array}$ \\
\hline $\begin{array}{l}\text { Meningkatkan Kewirausahaan } \\
\text { dan Pengembangan SDM }\end{array}$ & $\begin{array}{c}\text { Brunei } \\
\text { Darussalam, } \\
\text { Filipina, } \\
\text { Myanmar }\end{array}$ \\
\hline
\end{tabular}

Sumber: ASEAN Secretariat, 2019

Para pemimpin ASEAN sebakat bahwa pemfokusan implementasi SAP SMED dengan skema Country Champion, akan mampu membawa ASEAN kepada ketahanan usaha UMKM.

\section{Kondisi Pembangunan UKM di Indonesia}

UMKM merupakan pemain utama dalam perekonomian Indonesia, yang mewakili lebih dari 99 persen dari total bisnis di Indonesia. UMKM menghasilkan 57 persen dari total nilai tambah Indonesia dan mewakili 97 persen dari semua pekerjaan. Usaha mikro mendominasi sektor pertanian, usaha kecil paling banyak bergerak di sektor perdagangan dan hotel, sementara untuk usaha menengah masih kurang banyak. Namun, meskipun keberadaan UMKM di Indonesia berlimpah, kemungkinan mereka untuk dapat mengekspor produk mereka ke luar negeri masih terbatas, dibandingkan dengan perusahaan-perusahaan besar. Faktanya, UMKM di Indonesia sejak tahun 2014 hanya mencapai kurang dari 20 persen dari ekspor non-migas Indonesia, sebuah angka yang telah menurun sejak tahun 2008 (McClanahan, Chandra, Hattari, \& Vis-Dunbar, 2014).

Laporan SME Policy Index ASEAN 2018 memperlihatkan bahwa kepadatan UMKM Indonesia tergolong sangat tinggi, yaitu sekitar 22,1 UMKM per 100 orang. Pada tahun 2018, UMKM telah menyumbang sebesar $60 \%$ terhadap PDB dan menyediakan lapangan pekerjaan sebesar 96\% (Hartomo, 2019). Persentase yang tinggi tersebut masih diprediksi akan mengalami peningkatan, yaitu menjadi 65\% PDB pada tahun 2019. Kenyataannya, prediksi tersebut hampir mendekati, yang mana sepanjang tahun 2019, UMKM secara stabil menyumbangkan $60 \%$ terhadap PDB, dan $14 \%$ terhadap total ekspor nasional (Jawapos.com, 2020).

Undang-Undang Republik Indonesia Nomor 20 Tahun 2008 Tentang Usaha Mikro, Kecil, dan Menengah menunjukkan perhatian pemerintah pada pemberdayaan 
dan menciptakan iklim usaha yang ramah UMKM agar memperoleh pemihakan, kepastian, kesempatan, perlindungan, dan dukungan berusaha yang seluas-luasnya. Pemerintah juga mendukung UMKM melalui skema pembiayan dan pemberian jaminan pinjaman UMKM.

Indonesia ditetapkan oleh ASEAN sebagai Champion Country untuk tujuan strategis meningkatkan iklim peraturan dan kebijakan yang kondusif. Indonesia sebenarnya telah merumuskan kebijakan UKM yang mempromosikan efisiensi, dengan pertimbangan kesetaraan mulai digalakkan. Dalam menganalisis upaya Indonesia dalam mencapai tujuan strategis tersebut, berikut adalah kebijakan yang dikeluarkan sejak tahun 2016:

1) Peraturan Menteri KUMKM No. 14/Per/M.Kukm/Xi/2016 Tahun 2016:

Pedoman Koperasi Penyalur Kredit Usaha Rakyat

2) Peraturan Menteri KUMKM No. 8 Tahun 2018: Penyaluran Pinjaman/ Pembiayaan Dana Bergulir Oleh Lembaga Pengelola Dana Bergulir Koperasi, Usaha Mikro, Kecil \& Menengah

3) Peraturan Menteri KUMKM No. 2 Tahun 2019: Perizinan Berusaha Terintegrasi Secara Elektronik Bagi Usaha Mikro \& Kecil
4) Peraturan Menteri Pariwisata No. 16

Tahun 2019: Pedoman Pelaksanaan Teknis Kredit Usaha Rakyat Sektor Pariwisata

Perkembangan UMKM di Indonesia berada di bawah pengawasan Kementrian Koperasi dan Usaha Kecil Menengah Republik Indonesia. Saat ini, kebijakan terkait UKM tertuang dalam Rencana Strategis Lima Tahun yaitu 2015-2019, dengan menganggarkan dana sebesar Rp. 1.6777 triliun. Rencana tersebut sayangnya hanya memprioritaskan kebijakan sosial daripada tujuan daya saing ekonomi. Pendekatan dari rencana tersebut memandang UKM sebagai kelompok sosial yang membutuhkan bantuan daripada mesin pertumbuhan ekonomi yang laten. Selain itu, survei terhadap peserta dan pelaksana lokal dari program pengembangan UKM menunjukkan bahwa banyak program dilaksanakan sering kali berjalan tanpa penilaian menyeluruh terhadap kebutuhan UKM atau jaminan penuh terhadap kualitas manajemen. Mekanisme terbatas untuk memantau dan mengevaluasi dampak sebagaimana hasil survei tersebut, dapat menambah masalah dan hanya akan menghasilkan penggunaan sumber daya publik yang tidak ekonomis (OECD/ERIA, 2018).

Bank Indonesia mengemukakan 'filosofi 'lima jari; dalam upaya 
UMKM

untuk

mengibaratkan perlunya kerjasama lintas sektor untuk mencapai hasil yang maksimal (Bank Indonesia, 2013). Adapun filosofi tersebut meliputi: a) Lembaga Keuangan, berperan dalam intermediasi keuangan, terutama untuk memberikan pinjaman/pembiayaan kepada nasabah UMKM ; agen pembangunan; b) Regulator, yakni Pemerintah dan Bank Indonesia yang berperan dalam regulator sektor riil dan fiskal; menerbitkan ijin-ijin usaha; mensertifikasi tanah sehingga dapat digunakan oleh UMKM sebagai agunan; menciptakan iklim yang kondusif; sumber pembiayaan; c) Katalisator, berperan dalam mendukung perbankan dan UMKM; promoting Enterprise Access to Credit (PEAC) Units, perusahaan penjamin kredit; d) Fasilitator, berperan dalam mendampingi UMKM, khususnya usaha mikro; membantu UMKM untuk memperoleh pembiayaan bank; membantu bank dalam hal monitoring kredit, konsultasi pengembangan UMKM; e) UMKM, berperan sebagai pelaku usaha; pembayar pajak, pembukaan tenaga kerja.

Selama ini, berbagai fasilitas yang diberikan kepada UMKM di Indonesia dapat terbilang intens. Sejumlah fasilitas diberikan bagi UKM yang berpotensi untuk melakukan ekspor yaitu berupa Kredit Usaha Rakyat. Bank-bank yang berpartisipasi dalam program tersebut meliputi Bank Rakyat Indonesia, Bank Negara Indonesia, Bank Tabungan Negara, Bank Mandiri, Bank Syariah Mandiri, dan Bank Bukopin. Program Kredit Usaha Rakyat disesuaikan dengan UMKM dari berbagai sektor, meliputi sektor pertanian, perikanan, industri, kehutanan dan jasa keuangan.

Pusat Pelayanan UKM Indonesia juga menjadi salah satu fasilitas yang diberikan. Pusat Pelayanan UKM Indonesia melayani usaha mikro, kecil, dan menengah di seluruh negeri dengan menyediakan penggunanya informasi untuk akses keperluan finansial, SDM, pemasaran, dan hak kekayaan intelektual. Tujuan utama dari Pusat Pelayanan UKM Indonesia tersebut adalah untuk meningkatkan daya saing dan dinamisme UKM Indonesia. Pelayanan secara daring juga telah diinisiasi seperti Pusat Layanan Usaha Terpadu KUMKM atau Center for Integrated Services Small and Medium Enterprises and Cooperatives (CIS SMEsCO) berbasis android; web portal UKM Indonesia pertama yang menyediakan informasi lengkap seputar perizinan usaha di Indonesia; dan UMKM Go Online yang menjadi tag line digitalisasi UMKM Indonesia.

Lebih jauh, kegiatan pelatihan ekspor juga diutamakan demi menyiapkan 
UKM memasuki pasar bebas, khususnya pasar ASEAN. Direktorat Jenderal Pengembangan Ekspor Nasional, Kementrian Perdagangan telah memberikan program pelatihan bagi para eksportir di International Export Training Centre di Jakarta, dengan jangka waktu yang berkisar dari satu hari sampai dua bulan. Program ini dimaksudkan untuk meningkatkan pengetahuan, keterampilan dan daya saing eksportir Indonesia. International Ekspor Training Centre telah melatih lebih dari 45.000 peserta sejak pertama kali didirikan pada tahun 1990 (McClanahan, Chandra, Hattari, \& VisDunbar, 2014).

Demikian juga dengan pengarsipan pajak online, Indonesia telah merancang sehingga dimungkinkan melalui situs web Direktorat Jenderal Pajak, dan tampaknya sudah cukup maju. Kemudian Kementerian Komunikasi dan Informasi juga mulai mengadaptasi perangkat lunak Integrasi Informasi Manajemen dan Pertukaran Data (MANTRA) ke dalam portal untuk layanan e-government untuk memfasilitasi pertukaran data antara berbagai lembaga pemerintah (OECD/ERIA, 2018).

Sektor UKM di Indonesia telah banyak memperoleh dukungan agar mampu menciptakan daya saing yang tinggi. Selain itu, aktivitas produksi UKM telah menyediakan besarnya lapangan pekerjaan. Sesuai dengan model dari perspektif neoliberal institusionalisme bahwa pemerintah Indonesia berusaha menciptakan pembangunan kapasitas daerah dan pusat yang saling terhubung, memberikan akses ke koperasi atau pun bank sebagai lembaga pembiayaan, juga menciptakan pelatihan ekspor, dan memberdayakan lembaga promosi, dan fungsi regulasi yang mendukung.

Pada dasarnya, negara berkembang cenderung menyadari pentingnya potensi dan kontribusi UMKM terhadap perekonomian negara. Akan tetapi, dukungan untuk UMKM belum diberikan secara serius. Peran utama pemerintah dalam mendukung UMKM adalah penyediaan kebijakan publik yang mendukung transaksi privat, serta menyediakan infrastruktur.

Jika merujuk kepada kategori kebijakan pemerintah yang mendukung pembangunan UKM menurut Harvie \& Lee (2005), fokus Indonesia terhadap tujuan kebijakan makro, yaitu untuk mendorong pertumbuhan ekonomi dan ekspor, terlihat jelas. Pentingnya aspek perdagangan untuk menopang PDB negara mengakibatkan besarnya dorongan untuk dapat meningkatkan kegiatan ekspor.

Melalui peraturan menteri yang telah disebutkan di atas, juga menunjukkan 
bahwa kebijakan Indonesia juga ditujukan untuk mengoreksi ketidakefisienan pasar. Lebih jauh, meninjau program pembangunan dan penguatan UKM di Indonesia, dapat dilihat bahwa berbagai program tersebut secara langusng berhubungan dengan kehidupan dan kesejahteraan mayoritas masyarakat Indonesia. Jumlah UMKM yang dominan, tentu sektor ini menjadi objek vital dalam penopang pembangunan ekonomi Indonesia, apalagi dengan kemampuannya menyediakan lapangan pekerjaan. Pakpahan (2015) menggambarkan bahwa kebijakan publik Indonesia dalam mengakomodir pertumbuhan UMKM dapat disebut sebagai pro-poor, progrowth, pro-job (Pakpahan, 2015).

\section{Implementasi Kebijakan Pemerintah Daerah Kabupaten Bogor dalam Menerapkan MEA terhadap Sektor UKM Alas Kaki}

Produktivitas UMKM tentu dipengaruhi oleh penyelenggaraan peraturan oleh pemerintah daerah. Sebagaimana yang diketahui, penyelenggaraan otonomi daerah diamanatkan melalui UU No. 32 Tahun 2004 tentang Pemerintahan Daerah dan UU No. 33 Tahun 2004 tentang Perimbangan Keuangan antara Pemerintah Pusat dan Pemerintahan Daerah. Dalam laporan Kementerian Perencanaan
Pembangunan

Nasional/Badan

Perencanaan Pembangunan Nasional, dikaji bahwa dalam upaya meningkatkan Pendapatan Asli Daerah (PAD), banyak daerah yang menyusun Peraturan Daerah yang bertentangan dengan peraturan perundangan yang lebih tinggi sehingga justru menghambat perkembangan UMKM (BAPPENAS, 2010). Namun, meskipun demikian Bappenas juga menyatakan bahwa upaya secara signifikan telah dilakukan dalam meningkatkan produktivitas dan daya saing KUMKM, formalisasi UMKM, meningkatkan akses Koperasi UMKM pada berbagai sumberdaya yang produktif, serta meningkatkan jumlah Koperasi UMKM yang berbasis IPTEK didukung sistem pendataan, pemantauan, evaluasi dan pelaporan perkembangan dan pemberdayaan Koperasi UMKM (BAPPENAS, 2010).

Di Kabupaten Bogor, berdasarkan hasil wawancara dengan pihak Dinas Perindustrian dan Perdagangan, PEMDA Kabupaten Bogor sangat mendukung implementasi MEA di daerahnya, salah satunya dengan melakukan sosialisasi prosedur perizinan dan hak paten atas produk, termasuk mengenai standarstandar produk SNI. Kemudian berbagai upaya juga sudah dilakukan oleh pemda Kabupaten Bogor, seperti pelatihan 
(ekspor) dan bimtek untuk masuk ke pasar global (kalkulasi harga agar tidak terlalu mahal atau terlalu murah) secara gratis di mana sasarannya tentu saja adalah IKM. Namun sangat disayangkan pelaku IKM di daerah Kabupaten Bogor tidak begitu serius (seperti tidak hadir) dalam menyambut upaya-upaya pemda. Selain itu, bahan baku bagi pelaku IKM juga sering kali menjadi salah satu kesulitan sehingga harus membeli ke pihak lain atau dengan kata lain harus impor.

Bantuan permodalan terhadap UKM/IKM Alas Kaki di Kabupaten Bogor pernah diajukan untuk mendapatkan bantuan dari Kementerian Koperasi RI sebesar Rp. 50.000.000 melalui Koperasi Sepatu Bogor sekitar Tahun 2015 Pemerintah Daerah tidak pernah dilibatkan dalam perundingan terkait perdagangan di kementerian terkait sehingga semakin menyulitkan pemda untuk menyukseskan IKM itu sendiri. Kelemahan IKM yang terdapat di Indonesia dalam arus MEA terletak pada proses sertifikasi. Sertifikasi ini merupakan hal yang sangat krusial karena di dalam pasar global terdapat standarisasi tertentu. Namun belakangan, pemda setempat telah membantu mengurus sertifikasi tertentu agar IKM dapat bersaing dalam pasar MEA. Salah satu IKM lokal yang menyumbang kontribusi besar dalam pasar persaingan global dalam
MEA adalah jenis alas kaki yang terdapat di Ciomas, Kabupaten Bogor.

Rata-rata IKM yang berjalan dalam bidang alas kaki ini beroperasi dalam lingkup industri rumahan. Untuk mendukung terciptanya produk alas kaki yang berkualitas, pemda setempat telah berusaha untuk merangkul pekerja-pekerja industri rumahan ini karena produksi yang dilakukan oleh industri rumahan terbilang bagus. Tetapi, terdapat bias ketika pelaku home industry ini memproduksi barang agus (alas kaki) namun memakai brand ternama, seperti Nike, Adidas, dll. Sehingga, masyarakat hanya mengetahui bahwa produk yang mereka gunakan adalah produk-produk ternama, padahal, itu merupakan produk asli yang diproduksi oleh industri rumahantersebut. Dengan kata lain, industri rumahan belum percaya diri untuk menggunakan identitas produk mereka sendiri.

Dalam hal pemasaran, industri rumahan belum secara optimal melakukannya, sehingga lebih baik jika dibuat sentra khusus untuk IKM ini agar pemasaran dapat berjalan baik. Di dalam mengatur industri rumahanini, terdapat kesulitan dalam hal pemenuhan permintaan konsumen. Industri rumahan cenderung tidak dapat memenuhi permintaan secara rutin karena produksi dilakukan secara manual. Produk - produk 
IKM ini sudah banyak yang di ekspor namun melalui pihak ketiga. Jadi dalam hal ini, ketika produk industri rumahan sudah "terkenal", produsen pertama tidak akan tahu mengenai hal tersebut.

Bantuan untuk promosi dan sesi pameran terhadap UKM/IKM Alas Kaki di Kabupaten Bogor untuk promosi Produk Alas Kaki di Kab diikutsertakan dalam kegiatan-kegiatan pameran yang diadakan di Bogor maupun di luar Bogor, misalnya prov Bangka Belitung dan daerah lainnya. Pemerintah Kabupaten Bogor pada tahun 2011 mewajibkan semua PNS dan Non PNS di lingkup Pemerintahan Kab Bogor untuk menggunakan sepatu produk Kab Bogor.

Pelatihan keahlian diberikan dalam bentuk pelatihan mulai dari proses pembuatan sepatu, membuat pola, hingga mendesain alas kaki. Lama pelatihan perangkatan selama 3 hari. Sementara itu, pelatihan manajemen berupa pelatihan Gugus Kendali Mutu yang menyampaikan mengenai manajemen waktu agar hasil produk efisien dan efektif mengurangi tingkat kesalahan dan pemborosan bahan. Dilaksanakan selama 3 hari.

Pemerintah Kabupaten Bogor biasa memberikan masukan mengenai pembuatan desain produk yang sesuai dengan kenaikan pasar ekspor melalui kegiatan yng dilakukan oleh Dinas
Perdagangan dan Perindustrian Kabupaten Bogor, maupun melalui Kementerian Perindustrian. Namun, pelatihan ROO belum pernah dilaksanakan.

\section{Diskusi}

ASEAN SME Policy Index (2018) melaporkan bahwa dalam Rencana Strategis Kementerian Perindustrian 20152019 dialokasikan lebih dar Rp. 8,9 Milyar untuk program promosi klaster. Elektronik adalah salah satu sektor yang difokuskan, dan ada juga kelompok dalam agroindustri; teknologi informasi dan komunikasi (TIK); manufaktur; dan sektor kelautan, medis dan farmasi. Sementara untuk kebijakan inovasi, ditemukan bahwa UKM tidak dijadikan referensi khusus, dalam kebijakan inovasi nasional yang dipimpin oleh Kementerian Ristekdikti.

Tujuan selanjutnya yaitu meningkatkan akses pembiayaan, pasar \& internasionalisasi; dan meningkatkan iklim peraturan dan kebijakan yang kondusif; meningkatkan kewirausahaan \& pengembangan SDM juga telah diterjemahkan oleh Indonesia dalam berbagai langkah-langkah strategis.

Negara membutuhkan teknokrat yang mampu menciptakan kebijakan yang dapat menghubungkan UMKM dengan firma besar demi mengoptimalkan produksi dan memanfaatkan keterbukaan 
pasar. Berpijak berdasarkan tujuan strategis MEA dalam pembangunan UKM, pada dasarnya Indonesia telah bergerak menuju ketercapaian kelima tujuan yang dimuat dalam SAP-SMED.

Meskipun demikian, ketika penelusuran kebijakan dilanjutkan ke dalam sub-pemerintahan, dalam hal ini adalah pemerintah daerah, maka disadari bahwa terdapat banyak stakeholder yang memegang perananan penting. Dalam rangka meningkatkan kemampuan ekspor UMK alas kaki, justru ternyata keinginan dari para pelaku industri dan usaha yang belum tinggi. Ketika informasi mengenai keterbukaan akses pasar dan beragam upaya dilakukan berupa pelatihan sertifikasi ataupun internasionalisasi, namun belum menunjukkan hasil yang signifikan.

Pemerintah Kabupaten Bogor, melalui Dinas Perdagangan dan Perindustrian menanggapi MEA dengan serius dengan memberikan berbagai kegiatan pelatihan dan promosi kepada pelaku UKM/IKM. Lalu, kegiatan pendampingan yang dilakukan oleh Dinas Perdagangan dan Perindustrian Kabupaten Bogor bertujuan untuk meningkatkan ekspor komoditas non-migas yang ditargetkan dapat digalakkan oleh pelaku UKM/IKM.
Sayangnya, proses penentuan dan pengurusan ROO cukup rumit sehingga kegiatan untuk pengurusan tersebut masih di tataran profesional, yang mana pelaku bisnis diposisikan sebagai pihak yang mandiri dan memang siap untuk melakukan ekspor. Padahal, khusus untuk komoditas alas kaki, pasar domestik di Indonesia sudah menjadi pasar yang efektif bagi kebanyakan komoditas alas kaki yang dihasilkan oleh UKM/IKM. Sehingga, untuk kegiatan perdagangan internasional, aktivitas ekspor masih didominasi oleh pelaku industri besar alas kaki.

Jadi, UKM Indonesia yang dikenal tangguh dalam kegiatan perekonomian, namun nyatanya masih kalah bersaing jika disandingkan dengan industi atau usaha besar (large industries/enterprises). Oleh karena itu, penelitian ini melihat bahwa salah satu upaya yang dapat dilakukan adalah mengakomodir hubungan antar perusahaan. Misalnya antara UKM/IKM alas kaki dengan UM/IB alas kaki, baik yang berada di suatu provinsi ataupun lintas provinsi. Berbagai fasilitas yang disediakan oleh pemerintah dalam mendukung UKM, apabila melibatkan kerjasama yang memberikan jaminan peningkatan pendapatan atau kesejahteraan, akan menjadi motifasi bagi pelaku UKM. 
Rekomendasi di atas merujuk kepada konsep SME Inter-firm linkages (cooperation) dari Albert Berry (1997). Dinyatakan bahwa negara-negara seperti Korea, Jepang, Taiwan, Denmark, dan sejumlah negara di Amerika Latin telah mengupayakan hal tersebut. Misalnya di Taiwan, dibuktikan bahwa peningkatan ekspor oleh UKM disebabkan oleh adanya pemberian dukungan dari UB (Berry, 1997). UB, selain memiliki pengalaman memasuki pasar internasional, juga memiliki fasilitas dan kemampuan produksi yang lebih tinggi juga. Sehingga, apabila UKM telah mampu mengeskpor, UM akan bertindak sebagai penjamin produksi dalam memenuhi permintaan pasar.

\section{Kesimpulan}

Upaya Indonesia untuk membuktikan diri sebagai Country Champion dalam memenuhi tujuan strategis SAP-SMED termasuk signifikan. Indonesia yang memiliki beragam tantangan, seperti mengatasi lingkungan dengan peraturan yang kompleks, infrastruktur yang tidak memadai, distribusi sumber daya daerah yang tidak merata, serta kemiskinan \& pengangguran, telah perupaya untuk memberikan fasilitas melalui kebijakan publiknya.
Di Kabupaten Bogor, pertumbuhan nilai ekspor industri alas kaki masih didominasi oleh industri besar meskipun berbagai pembinaan untuk industri kecil dan menengah telah dilakukan. Karena itu, pemerintah daerah sebagai pengambil dan pelaksana kebijakan juga harus mendesain kebijakan mereka dalam kerangka membela kepentingan industri kecil \& menengah.

Tulisan ini menggarisbawahi pentingnya fasilitas yang mampu mewujudkan kerjasama antar perusahaan. Tepatnya Kerjasama antara UKM/IKM dengan IB/UB. Kerjasama yang baik kelak akan mewujudkan implementasi kebijakan yang telah dibuat oleh pemerintah Indonesia. Hal ini dapat terwujud dengan kemudahan birokrasi dan bantuan keuangan bagi keterjaminan UKM. Pengawasan \& evaluasi juga sehendaknya menjadi kesatuan yang tidak terpisah dalam implementasi kebijakan, termasuk untuk kebijakan pemerintah daerah dalam penerapan MEA terhadap sektor usaha kecil dan menengah di Kabupaten Bogor.

\section{Referensi}

ASEAN. (2007). ASEAN Economic Community Blueprint. Jakarta: ASEAN Secretariat.

ASEAN Secretariat. (2019). ASEAN Strategic Action Plan for SME 
Development 2016-2025. Jakarta:

ASEAN Secretariat.

ASEAN. (t.t.). Overview: SME Developments in ASEAN. Retrieved from

ASEAN:

https://asean.org/asean-economic-

community/sectoral-bodies-under-

the-purview-of-aem/micro-small-

and-medium-enterprises/overview/

Bank Indonesia. (2013). Info UMKM.

Retrieved from Bank Indonesia: https://www.bi.go.id/id/umkm/koor dinasi/filosofi-lima-

jari/Contents/Default.aspx

BAPPENAS. (2010). Laporan Akhir

Kajian Pemetaan dan Evaluasi

Efektivitas: Regulasi Sektoral dan

Desentralisasi

Terhadap

Pelaksanaan Otonomi Daerah.

Jakarta: BAPPENAS.

Bateman, M. (2000). Neo-Liberalism, SME Development and the Role of

Business Support Centres in the

Transition Economies of Central and Eastern Europe. Small Business Economics, 275-298.

Berry, A. (1997). SME Competitiveness:

The Power of Networking and

Subcontracting.

Chin, Y.-W., \& Lim, E.-S. (2018). SME

Policies and Performance in

Malaysia. ISEAS - Economics

Working Paper, 1-40.
Eniola, A. A., \& Entebang, H. (2015). Government Policy and Performance of Small and Medium Business Management. International Journal of Academic Research in Business and Social Sciences, 2(5), 237-248.

Eshima, Y. (2003). Impact of Public Policy on Innovative SMEs in Japan. Journal of Small Business Management, 41(1), 85-93.

Gilpin, R. (2001). Global Political Economy : Understanding the International Economic Order. New Jersey: Princeton University Press.

Hartomo, G. (2019, Juny 19). UMKM Sumbang Rp8.400 Triliun ke Perekonomian Nasional pada 2018. Retrieved from Okezone.com: https://economy.okezone.com/read/ 2019/06/19/320/2068296/umkmsumbang-rp8-400-triliun-keperekonomian-nasional-pada-2018 Harvie, C., \& Lee, B. C. (2005). Sustaining Growth and Performance in East Asia The Role of Small and Medium Sized Enterprises. Cheltenham, UK: Edward Elgar Publishing.

INTRA. (2015). MEA Pintu Masuk Masyarakat Dunia. Retrieved from 
Kementerian

Perdagangan

Republik

Indonesia:

http://www.kemendag.go.id/files/p

df/2016/01/29/

Kemendag_INTRA_VIII_Layout_

Design_WebRes.pdf

Jawapos.com. (2020, Januari 16).

Akumindo Yakin Kontribusi

UMKM Tahun ini Capai Rp

2.394,5 Triliun. Retrieved from

Jawapos.com:

https://www.jawapos.com/ekonomi

/16/01/2020/akumindo-yakin-

kontribusi-umkm-tahun-ini-capai-

rp-2-3945-triliun/

Kementerian Luar Negeri Republik

Indonesia. (2012). ASEAN

Selayang Pandang Edisi ke-20,

Tahun 2012. Jakarta: Direktorat

Jenderal Kerja Sama ASEAN.

Kementerian Perindustrian Republik

Indonesia. (2019). Pangsa Pasar

Lampaui 4 Persen, Industri Alas

Kaki Peringkat Ke-5 Dunia.

Retrieved from Kementerian

Perindustrian Republik Indonesia:

http://kemenperin.go.id/artikel/176

05/Pangsa-Pasar-Lampaui-4-

Persen,-Industri-Alas-Kaki-

Peringkat-Ke-5-Dunia

McClanahan, P., Chandra, A., Hattari, R.,

\& Vis-Dunbar, D. (2014). Taking

Advantage of ASEAN's Free Trade
Agreements: A Guide for Small and

Medium-Sized Enterprises.

International Institute for

Sustainable Development.

OECD/ERIA. (2018). SME Policy Index: ASEAN 2018: Boosting Competitiveness and Inclusive Growth. Paris \& Jakarta: OECD Publishing \& Economic Research Institute for ASEAN and East Asia. Pakpahan, A. K. (2015). The Development of Business Clusters in Indonesia. Baden-Baden: Bloomsbury Publishing.

Parameswaran, P. (2017, February 16). What's Next for Japan-Philippines

Situmeang, N., Dharmastuti, S., \& Nashir, A. (2016). Upaya Pemerintah Daerah Kabupaten Bogor dalam Meningkatkan Daya Saing Ukm Sektor Tekstil Menghadapi Asean Economic Community. Global Komunika, 58-66.

Trade Facilitation Office Canada dan The Conference Board of Canada. (2017). Laporan Riset Pasar: Alas Kaki. Retrieved from CanadaIndonesia Trade and Private-Sector Assistance: http://www.tpsaproject.com/wpcontent/uploads/2017-02-28-

Report-IDN-1212.01b.pdf 